\title{
O "CÍRCULO HERMENÊUTICO" COMO ESTRUTURA, O "ENQUANTO" DA HERMENÊUTICA FILOSÓFICA
}

Luiz Rohden*

SÍNTESE - Pretendemos contribuir à afirmação e ao reconhecimento da hermenêutica filosófica mostrando que ela é mais que um instrumento da filosofia, mas seu modo próprio de ser. Por isso, nós tentamos reinterpretar a origem míticoetimológica da hermenêutica e mostrar que o círculo hermenêutico constitui a estrutura, o "enquanto" da mesma.

PALAVRAS-CHAVE - Hermes. Mito. Hermenêutica. Círculo hermenêutico. Pré-compreensão. Compreensão. "Enquanto".
ABSTRACT - We intend to contribute to the affirmation and recognition of the philosophical hermeneutic showing that hermeneutics is more than an instrument of the philosophy but its own way of being. So we try to reinterpret the mythicetymological origin of the hermeneutics and to show that the circle hermeneutic constitutes the structure, the 'while' of the hermeneutics.

KEY WORDS - Hermes. Myth. Hermeneutic. Circle hermeneutic. Pre-understanding. Understanding. "While".

"O diálogo que está em curso se subtrai a qualquer fixação. Mau hermeneuta é o que crê que pode ou deve ficar com a última palavra."1

\section{Introdução}

Chegou o tempo de a hermenêutica afirmar-se e ser reconhecida enquanto filosofia! Para isso pode contribuir nossa presente reflexão.

Algumas críticas gerais dirigidas contra a hermenêutica. Em geral, mal vista, e considerada como a 'arte da interpretação', a hermenêutica ficou reduzida a uma 'ferramenta' necessária para interpretar textos literários, jurídicos, teológicos. H. Schnädelbach apresenta a posição de R. Brandt para quem há uma 'interpreta-

* Professor da Universidade do Vale do Rio dos Sinos (UnISINOS) e doutorando em Filosofia no Curso de Pós-Graduação em Filosofia da PUCRS.

1 "Das Gespräch, das im Gange ist, entzieht sich der Festlegung. Ein schlechter Hermeneutiker, der sich einbildet, er könnte oder er müsste das letzte Wort behalten" (GADAMER, H. G. Hermeneutik II: Wahrheit und Methode. - 2. Ergänzungen, Register. - 2. Aufl. - 1993, p. 478). 
ção objetivamente-determinada' e outra 'subjetivamente-reflexiva'. Entre ambas, para R. Brandt, não há circularidade hermenêutica e, havendo, deve ser rompida. ${ }^{2}$ Mas não passa de uma 'arte' (inferior à epistéme, às ciências no sentido moderno), um apêndice da própria filosofia. Atividade relativa a cada um, pura subjetividade, opinião pessoal. Relativa por que não é universal, não tem reconhecimento nem validade espaço-temporal. Incomparável e incompativel à objetividade das ciências, arbitrária, sem cientificidade, estrutura e método definidos.

Habermas reconhece a superioridade da hermenêutica em relação à dialética, mas vê nela uma série de limites: "o compreender hermenêutico move-se no domínio da comunicação da linguagem ordinária, por isso, ele perde sua competência nas esferas onde as proposições ultrapassam o domínio da linguagem ordinária" e "a hermenêutica também não é competente onde não apenas a comunicação, mas a própria linguagem está perturbada; linguagem em cujo contexto as perturbações de comunicação deveriam ser trabalhadas". ${ }^{3}$ Lembramos que, para Apel, a hermenêutica é relativista e seu grande limite refere-se à sua falta de validade.

Aos desafios colocados qual nossa posição e perspectiva. Frente ao desenvolvimento, seja das ciências, seja da filosofia analítica, a hermenêutica foi e continua sendo considerada como um apêndice, nem sequer ainda delas, mas apenas da dialética. Os limites e problemas apresentados constituem desafios, não a serem eliminados ou resolvidos, mas que nos convidam a filosofar ...

Propomo-nos, neste artigo, não só salvar a hermenêutica filosófica de tais concepções limitadas e incoerentes, mas mostrar que ela, além de não ser um simples 'instrumento' de trabalho para a filosofia e ciências humanas, possui uma identidade com uma estrutura e 'metodologia' própria. Pretendemos afirmar, não apenas em oposição às ciências e correntes da filosofia pela via da negação, defensivamente, mas, positivamente, sua identidade e, quem sabe, contribuirmos para a passagem da sua infância à 'maioridade'.

Preocupados em apresentar aqui aspectos fundamentais da hermenêutica filosófica, mostraremos que ela tem uma origem, uma história, uma 'estrutura', que nomearemos como "enquanto", que não podem ser ignorados ou suprimidos no processo do conhecimento humano.

2 "Der hemeneutische Zirkel soll aufgesprengt werden, und zwar in beiderlei Gestalt; das zirkuläre Verstehen des Ganzen eines Textes aus seinen Teilen und umgekehrt wird ebenso wie die Unübersteiggbarkeit eines im jeweiligen Verstehen je schon wirksamem Vorverständnisses vom Verfasser als mit Gründen destruierbares Vorurteil hingestellt". (A obra de Reinhard Brandt chamase Die Interpretation philosophischer Werke. Eine Einführung in das Studium antiker und neuzeitlicher Philosophie"). SCHNÄDELBACH. Herbert. Die Sprengung des hermeneutischen Zirkels. "Philosophische Rundschau", Tübingen, 35. Jahrgang, Heft 1/2, 1988, p. 41 e $42 . \mathrm{Na} \mathrm{p.} 43 \mathrm{H}$. Schnädelbach retoma texto de R. Brandt: "'Es zeigten sich zwei grundsätzlich verschiedene Zugangsformen zu philosophischen Texten: Die eine subsumiert die fremden Gedanken unter eigene Ideen und stellt die empirische Untersuchung unter ein inhaltlichers Aprion. Die andere versucht umgekehrt, methodisch von der eigenen Überzeugung zu abstrahieren und objetikv zu bestimmen, was eine andere Theorie sagt und wie es sie begründet (31)". 


\section{Sobre a origem mítico-etimológica ${ }^{4}$ da hermenêutica}

A hermenêutica tem uma história que remonta à mitologia grega ${ }^{5}$ e acompanhou a reflexão filosófica de Platão, Aristóteles, S. to Agostinho, B. Espinoza, F. Schleiermacher, W. Dilthey, M. Heidegger, H.G. Gadamer, Paul Ricoeur e muitos outros. Independente das acusações que foram e continuando sendo dirigidas à hermenêutica, o dado histórico, a tradição constituem faces que atestam sua existência, que revelam uma espécie de 'objetividade'. Historicamente ela foi apresentada com um sentido, uma metodologia e finalidade próprias. Revisitar a história da hermenêutica quer ser um testemunho 'objetivo', 'incontestável' da hermenêutica para liberá-la da acusação, tout court, de relativismo ingênuo.

Em obras clássicas de hermenêutica como Richard Palmer, Hermenêutica; Josef Bleicher Hermenêutica Contemporânea; Emerich Coreth Ouestões Fundamentais de Hermenêutica, podemos encontrar delineado seu itinerário o que nos isenta da tarefa de apresentar aqui todo seu trajeto histórico. Da dimensão histórica tomaremos apenas a origem etimológico-mitológica da hermenêutica que, além de pouco conhecida, contém uma série de elementos significativos que resgataremos $^{6}$ na segunda parte de nosso trabalho.

Como muitos outros filósofos que retomaram o mito em suas reflexões, Heidegger, para mostrar o que compreendia por 'cura (cuidado)', e com isso seu 'constructo filosófico', utilizou-se da fábula de Higino, em Ser e Tempo, § 42.7 Nós apresentamos aqui o mito de Hermes, seu nascimento, sua representação, suas funções e características, não arqueologicamente, mas compreensivamente filosófica. O mito é algo vivo, criativo, que faz e é criador de sentido para nós hoje, eis por que o retomamos. Embora isso seja contestado pelas ciências, pensamos que o mito possui uma criatividade e atualidade superior, inclusive, às mesmas. De acordo com Andrés Ortiz-Osés, na hermenêutica contemporânea "Hermes é o

4 De acordo com G. Ebeling "die etymologische Herkunft von $\varepsilon \rho \mu \eta v \varepsilon v \omega$ samt Derivaten ist umstriten, weist aber auf Wurzeln mit der Bedeutung 'sprechen', 'sagen' (zusammenhängend mit lat. 'verbum' oder 'sermo') Die Vocabel hat drei Bedeutungsrichtungen: aussagen (ausdrücken), auslegen (erklären) und übersetzen (dolmetschen)" (Hermeneutik, in Enc. Religion und Geschichte, 3 rd:, v. 3. p. 243).

5 A propósito disso ver o capítulo "1, O mito e sua interpretação" in La Interpretación de los símbolos: hermenêutica y lenguaje en la filosofia actual de Luis Garagalza. Barcelona: Antropos, 1990, p. 91-108.

6 Lembramos que este artigo constitui uma parte de um todo que pretendemos desenvolver ao longo dos próximos anos.

7 O prof. Stein apresentou-o da seguinte maneira: "quando um dia o Cuidado atravessou um rio, viu ele terra em forma de barro: meditando, tomou uma parte dela e começou a dar-lhe forma. Enquanto medita sobre o que havia criado, aproxima-se Júpiter. O Cuidado lhe pede que dê espírito a esta figura esculpida com barro. Isto Júpiter lhe concede com prazer. Quando, no entanto, o Cuidado quis dar seu nome a sua figura, Júpiter o proibiu e exigiu que lhe fosse dado o seu nome. En. quanto o Cuidado e Júpiter discutiam sobre os nomes levantou-se também a Terra e desejou que à figura fosse dado o seu nome, já que ela tinha oferecido uma parte do seu corpo. Os conflitantes tomaram Saturno para juiz. Saturno pronunciou-lhes a seguinte sentença, aparentemente justa: Tu, Júpiter, porque deste o espirito receberás na sua morte o espirito; tu, Terra, porque lhe presenteaste o corpo, receberás o corpo. Mas porque o Cuidado por primeiro formou esta criatura, irá o Cuidado possui-la enquanto ela viver. Como, porém, há discordância sobre o nome, irá chamar-se homo já que é feita de humus' (STEIN, E., Seis estudos sobre 'Ser e Tempo'. Petrópolis: Vozes, 1990, p. 87. 88). 
deus do sentido, porquanto põe em comunicação e correlação os diferentes níveis de uma realidade aberta por seu verbo alado". 8

$\mathrm{Na}$ tentativa de apresentar, com certa 'objetividade', a origem míticoetimológica da hermenêutica, podamos o potencial criador do mito de Hermes e estamos cometendo uma contradição. Mesmo assim, assumimos nossa postura de tentar explicitar aqui no mito o que nos interessa, mais diretamente à hermenêutica e ao nosso propósito inicial de mostrar de sua identidade. Em outras palavras, assumimos os riscos de escrever sobre o mito, sobre a hermenêutica, sobre o dito que não pode ser dito totalmente.

O termo hermenêutica tem sua origem na mitologia grega, mais especificamente em Hermes ou Mercúrio (em grego E $\mu \eta\rceil \sigma \zeta$; em latim Mercurius) e o vocá-

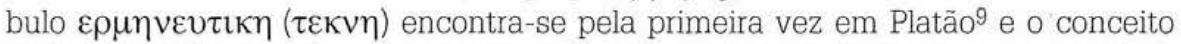
de hermenêutica encontra-se como título de livro em J. D. Dannhauer em 1654.

Nascimento: Afirma-se que nasceu num dia 4, numa caverna do monte Cilene, ao sul da Arcádia. Narra o mito que, "apesar de enfaixado e colocado no vão de um salgueiro, árvore sagrada, símbolo da fecundidade e da imortalidade, o que traduz, de saída, um rito iniciático, o menino revelou-se de uma precocidade extraordinária. No mesmo dia em que veio à luz, desligou-se das faixas, demonstração clara de seu poder de ligar e desligar [...]". ${ }^{10}$ Só Hermes, filho de Maya, da união com Zeus, é deus; os restantes são mortais apesar de serem filhos de deuses, à exceção de Sísifo, "o que contravém a um princípio geral da mitologia clássica, segundo a qual são deuses os filhos de duas divindades e mortais os filhos de um deus e uma mortal ou de uma deusa e um mortal [...]".11

Representação: O deus Hermes "tinha sua imagem colocada nas encruzilhadas, local de orientação, sob a forma de colunata, encimada da cabeça do deus. A essas colunatas ou pilares se dava o nome de $\varepsilon \rho \mu \alpha \tau \alpha$, 'apoio, cipo, coluna' a que parece prender-se o nome Hermes'. ${ }^{12}$ É apresentado também com um chapéu, com sandálias providas de asas e segurando um caduceu ou vara de ouro.

Teágenes sustentava, e foi o primeiro a fazê-lo, que "para Homero os deuses Apolo, Hélio, Hefesto, Poseidon, Ártemis, Hera, Atená, Ares, Afrodite e Hermes não eram mais que outras maneiras de nomear ao fogo (os três primeiros), à água (Poseidon), à lua (Ártemis), ao ar (Hera), à inteligência (Atená), à estultice (Ares), ao desejo (Afrodite) e à linguagem (Hermes)'.13

Mitos: Hermes, recém-nascido ainda, roubou parte de um rebanho de Apolo e escondeu-o numa gruta e à saída desta encontrou uma tartaruga que matou e com a carapaça e tripas desta fez a primeira lira. ${ }^{14}$ Mas Apolo, o deus mântico,

8 ORTIZ-OSÉS, Andrés. El sentido, lo sublime y lo sublimal. In: El retomo de Hermes: hermenéutica y ciencias humanas. Alain Verjat (ed.). Barcelona: Antropos, 1989, p. 164.

9 Epinomis, 975, c. cf. EBELING, G. Hermeneutik. In: Enc. Religion und Geschichte, 3 rd., v. 3. p. 243.

10 BRANDÃO, J. de Souza. Mitologia grega. Petrópolis: Vozes, 1986, v. 2, p. 191.

11 De ELVIRA, Antonio Ruiz. Mitología clásica. Madrid: Gredos, 1984, p. 40.

12 Brandão, op. cit., p. 191.

13 "Segundo parece deduzir-se de um escólio anônimo do códice de Vêneto 453 da Ilíada (schol. B II. XX 67, escólio que, como tantos outros, desde Schrader sói considerar-se procedente das Cuestio-

14 nes homéricas de Porfírio, 
descobriu o paradeiro de Hermes e acusou-o perante sua mãe (Maya) que nȩ pois ele era apenas um recém-nascido. Apolo acusa o pai de Hermes que inten ga o filho que se defende e nega o furto. "Convencido de mentira pelo pai e obri gado a prometer que nunca mais faltaria com a verdade, Hermes concordou, acrescentando, porém, que não estaria obrigado a dizer a verdade por inteiro." A ele atribui-se também a invenção da "flauta de Pã" que Apolo desejou e em troca deu-lhe seu cajado de ouro o qual pediu ainda lições de adivinhação. Hermes aperfeiçoou sua arte divinatória, "auxiliando a leitura do futuro por meio de pequenos seixos". ${ }^{15}$

Funçöes: De acordo com Antonio Ruiz, atribui-se-lhe também "a invenção da palavra e das línguas bem como (Hor. Carm. I 10, 1-3, Hyg. Fab 143, etc.), da lira, do fogo, e da flauta (Hom. Hymn. IV 25, 108-11; 511; Pausan. V 14, 8, etc.) hábil em toda classe de furtos e enganos, protetor dos mentirosos e ladrões (por isso são assinalados ladrões ou embusteiros seu filho Autólico e seu bisneto Ulisses; e ele é quem faz mentirosa e infiel a Pandora em Hes. op. 67 e 68), psicopompo ou condutor das almas ao Inferno, patrocinador do comércio: tais são as principais funções que se lhe atribuem". ${ }^{16}$

Hermes é uma divindade complexa, "com múltiplos atributos e funções" que parece ter sido inicialmente um deus agrário, protetor de pastores, sendo representado também com um carneiro sobre os ombros. ${ }^{17}$

Os escritores e poetas lhe dignificaram as prerrogativas. Na Iliada, c. XXIV, 334 ss., vendo o alquebrado Príamo ser conduzido por Hermes através do acampamento aqueu, Zeus exclama comovido: "Hermes, tua mais agradável tarefa é ser o companheiro do homem; ouves a quem estimas". Na Odisséia VIII, 335, Homero afirma: "Hermes, mensageiro, filho de Zeus, é o dispensador de bens". Afirma-se que se tornou, juntamente com Dionísio, o "menos olímpico dos imortais". 18

Era considerado o protetor dos viajantes, o deus das estradas. Como "guardião dos caminhos, cada transeunte lançava uma pedra, formando um $\varepsilon \rho \mu \alpha \iota o v$ (hérmaion), isto é, literalmente, 'lucro inesperado, descoberta feliz' proporcionados por Hermes: assim, para agradecerem ou para se obterem bons lu-

15 Id., ibid., p. 192.

16 Como já vimos, também para Antonio Ruiz, "os dois mitos mais célebres de Hermes são a fabricação da lira, com uma tartaruga que se encontra diante da cova em que havia nascido (Himn. Hom. IV 17, 24-54), e o roubo das vacas de Apolo (Hymn. Hom. IV 68-102, Ov. Met.II 685-707, Apollod. III 10, 2, Anton. Lib. 23, Pausan. VII, 20, 4, Philostr. Imag. I 26), façanhas que realiza no mesmo dia de seu nascimento: nascido na aurora, fabrica a lira ao meio-dia e efetua o roubo ao anoitecer. Para este roubo que tem lugar em Pieria (ao norte do Olimpo), de onde Hermes leva cinqüenta vacas até Pilos (não a mais famosa Pilos, que é a de Mesênia, senão a Pilos de Trifilia, junto ao rio Alfeo, no Peloponeso ambas), inicia por inverter as pegadas do gado "fazendo que os cascos dianteiros fossem traseiros e os traseiros dianteiros e marchando ele também ao contrário' (Hymn. Vv. 76-78)", op. cit., p. 89-90. Brandão, op. cit., p. 192.

18 Id., ibid., p. 193. Os gregos ampliaram suas funçōes e por seu furto "se tornou o símbolo de tudo quanto implica astúcia, ardil e trapaça: é um verdadeiro trickster, um trapaceiro, um velhaco, companheiro, amigo e protetor dos comerciantes e dos ladrões". Na tragédia Reso o deus é chamado 'Senhor dos que realizam seus negócios durante a noite'. 
cros, formavam-se, em honra do deus, verdadeiros montes de pedra à beira da estrada". ${ }^{19}$

Quanto ao mito da 'fabricação' da mulher, como o castigo que teria de substituir a privação do fogo, por ordem de Zeus, foi Hermes quem lhe pôs "o nome de Pandora porque 'todos os deuses outorgaram seus dons' (Op. 81-83)". ${ }^{20}$ Como deus da linguagem podia nomear as coisas, as pessoas, o que é muito significativo à hermenêutica como veremos.

Zeus ordenou Hermes que recuperasse a vaca (no caso era Io que foi transformada em vaca e com quem Zeus já dormira e que fora tirada dele por Argos); que, para conseguir realizar tal pedido, adormece a Argos Panoptes com a música de sua flauta e o mata depois. ${ }^{21}$

Zeus, irritado com Hércules que roubara vacas e éguas e assassinara um hóspede em sua própria casa, envia Hermes para que o venda como escravo. ${ }^{22}$ Como vimos, Hermes ajudava tanto os deuses como os homens. ${ }^{23}$ Salvou, por exemplo, Ulisses do feitiço que Circe lhes lançara. ${ }^{24}$

Características: Além das funções e características já apresentadas mostraremos outras, referidas direta e indiretamente à hermenêutica como explicitaremos mais adiante. "Para os gregos Hermes regia as estradas, porque andava com incrivel velocidade, pelo fato de usar sandálias de ouro, e, se não se perdia na noite, era porque, 'dominando as trevas', conhecia perfeitamente o roteiro [...] conhecedor dos caminhos e de suas encruzilhadas, não se perdendo nas trevas, sobretudo podendo circular nos três níveis, o filho de Maya acabou por ser um deus psicopompo, quer dizer, um condutor de almas, tanto do nível telúrico para o ctônico quanto deste para aquele."25

Sem dúvida a "grande tarefa de Hermes, no entanto, consistia em ser o intérprete da vontade dos deuses. Após o dilúvio, foi o portador da palavra divina a Deucalião, para anunciar que Zeus estava pronto a conceder-lhe a satisfação de um desejo. Por intermédio dele, o consumado músico Anfião recebeu a lira, Héracles, a espada, Perseu, o capacete de Hades. [...] Por ordem expressa de Zeus, cumpriu a ingrata missão de levar a Prometeu, aguilhoado a uma penedia, o ultimatum, para que revelasse o grande segredo que tanto preocupava o pai dos deuses e dos homens. A ele coube, igualmente, a gratíssima tarefa de conduzir Pisqué para o Olimpo, a fim de que se casasse com Eros". ${ }^{26}$

19 Id., ibid., p. 193.

20 De Elvira, op. cit., p. 117-118.

21 Id., ibid, p. 126.

22 Id., ibid., p. 240.

23 Hermes conforta Perseu em seu desconsolo quando fora convidado a participar de um banquete no qual pretendiam desfazer-se dele por causa dos interesses que possuiam por mãe. Nele fora provocado por causa de uma pretendente sua e exciama que daria muitos regalos inclusive, se necessário, trazer a cabeça de uma Medusa (por sua pretendente). Ele então se dá por conta do que prometera e desconsola-se. Ai vem Hermes como consolador, que também lhe dá uma cimitarra para poder cortar a cabeça da Medusa. Assim, com a ajuda de Hermes levou a bom termo seu empreendimento (Id., ibid., p. 156-157.

26 Id., ibid., p. 193-194.

Id., ibid., p. 195. 
É importante salientar a relação que Hermes tem com o mundo dos homens, “um mundo por definição 'aberto', que está em permanente construção, isto é, sendo melhorado e superado" 27 como interpreta Mircea Eliade.

Vimos anteriormente que Hermes recebeu de Apolo o caduceu e lições de mântica. ${ }^{28}$ De acordo com J. P. Vernant o processo oracular ocorria da seguinte maneira: "O consultante penetra na ágora, ao cair da noite. Dirige-se de início à Lareira. Queima incenso, enche as lamparinas de óleo, acende-as. Deposita sobre o altar de Héstia uma moeda da região, sem dúvida sagrada, que recebe o nome de 'bronze'. Só então ele se volta para Hermes e diz ao ouvido do deus a pergunta que deseja fazer. Depois, tapa as orelhas com as mãos e, nesta posição, vai andando até sair do local. Logo que ultrapassa o períbolo e que chega fora, retira suas mãos das orelhas, e a primeira voz que ouvir em seu caminho fornece-lhe a resposta do deus." 29 Importante para nossa reflexão são os seguintes aspectos desse oráculo que realça "o aspecto móvel de Hermes", em quem a resposta do seu deus se descobre: "1. pelo próprio movimento do consulente que deve se pôr em marcha para conhecê-la; 2. no momento em que, deixando o recinto da ágora, ele chega ao espaço exterior; 3. no fato de apanhar no ar uma voz - esta $\varphi$ ov $\eta$ móvel, ligeira, intangivel - a voz da primeira pessoa que o acaso fez com que cruzasse seu caminho; 4. na distância que o oráculo estabelece entre a questão, posta no centro da ágora, como é deposta no centro, para sempre permanecer aí, o preço da consulta, e a resposta que o deus dá a conhecer fora, em um outro espaço que aquele onde se ergue sua própria imagem". ${ }^{30}$

J. P. Vernant apresenta a relação com Héstia representa "o interior, o recinto, o fixo, a intimidade do grupo em si mesmo; a Hermes o exterior, a abertura, a mobilidade, o contato com o outro". ${ }^{31}$

Diferente dos demais deuses ${ }^{32}$ que vivem no além, Hermes é um deus próximo dos homens. Aristófanes vê nele o mais 'amigo dos homens'. ${ }^{33}$ Estando na terra, habitando na terra dos mortais, ele o faz à maneira de mensageiro, "como um viajante que vem de longe e que já se apressa a partir. Não há nele nada fixo, estável, permanente, circunscrito, nem fechado. Ele representa, no espaço e no mundo humano, o movimento, a passagem, a mudança de estado, as transições, os contatos entre elementos estranhos. Na casa, o seu lugar é junto da porta, protegendo a soleira, afastando os ladrões porque ele próprio é o Ladrão '(Hermes,

27 Mircea Eliade, p. 109, apud Brandão, op. cit., p. 195-196.

28 Brandão, id., p. 202-203. A primeira interpretação nos é oferecida por Junito de S. Brandão, para quem, com o poder mântico que possuía respondia "às consultas de seus devotos pelo denominado processo das vozes. Purificado, provavelmente com o mais simples processo da ablução, o consulente dirigia-se para o fundo do templo, onde estava a estátua de Hermes e dizia-lhe baixinho ao ouvido o seu desejo secreto. Em seguida, tapava fortemente as orelhas com as mãos e caminhava até o átrio do templo, onde, num gesto rápido, afastava as mãos: as primeiras palavras ouvidas dos transeuntes eram a resposta do oráculo e a decisão de Hermes".

29 VERNANT, Jean-Pierre. Mito e pensamento entre os gregos: estudos de psicologia histórica. Rio de Janeiro: Paz e Terra, 1990, p. 187.

30 Id., ibid., p. 188.

31 Id., ibid., p. 155.

32 Hermes mereceu o "quinto hino órfico: tu, mensageiro do deus, profeta do lógos para os mortais" (Brandão, op. cit., p. 207.

33 ARISTÓFANES, A paz, 392, apud Vemant, op. cit., p. 153. 
o Salteador, O-que-vagueia-diante-das-portas, o Espreitador noturno)'34 aquele para quem não existe nem fechadura, nem cerca, nem fronteira: o Passa-Muros que o Hino a Hermes nos mostra 'resvalando obliquamente através da fechadura, semelhante à brisa de outono, como um nevoeiro'. ${ }^{35}$ Presente diante das portas ele reside também na entrada das cidades, nas fronteiras dos Estados, nas encruzilhadas, ao longo das pistas, marcando o caminho, sobre os túmulos [...]". ${ }^{36} \mathrm{Em}$ bora presente "no meio dos homens, Hermes é ao mesmo tempo intangível, ubiqüitário. Não está nunca onde está, aparece repentinamente e desaparece [...] Ele usa o capacete de Hades que o torna invisivel, as sandálias aladas, que anulam as distâncias, e uma varinha de mágico que transforma tudo o que toca. É também aquilo que não se pode nem prever nem reter, o fortuito, a boa ou a má sorte, o encontro inesperado; o ganho se diz em grego $\tau$ o $\varepsilon \rho \mu \alpha \iota v^{\prime \prime} .{ }^{37}$

Não poucos pensadores retomaram o mito de Hermes em suas reflexões. Presentemente, Italo Calvino fê-lo apresentando Hermes com as seguintes características: "Mercúrio, de pés alados, leve e aéreo, hábil e ágil, flexível e desenvolto, estabelece relações entre os deuses e entre os deuses e homens, entre as leis universais e os casos particulares, entre as forças da natureza e as formas de cultura, entre todos os objetos do mundo e todos os seres pensantes". ${ }^{38}$

\section{Sobre o círculo hermenêutico em F. Schleiermacher, M. Heidegger e H.G. Gadamer}

Pretendemos mostrar que a hermenêutica, além de uma história, tem uma estrutura, diferente da das ciências naturais, que pode ser representada pelo 'jogo', 'círculo hermenêutico', 'diálogo'. Nós desenvolveremos aqui apenas o 'círculo hermenêutico' uma vez que ele constitui um nó de ligação entre as críticas à hermenêutica e a possibilidade de sua 'mostração'. Crítica porque os lógicos vêem no círculo hermenêutico um círculo vicioso e nós mostraremos que ele é a estrutura própria da hermenêutica. Luis Garagalza, p. ex., ao refletir sobre "Hermes e o sentido" sabia da circularidade em que se move todo o conhecimento, do qual não se pode escapar, mas que não se resolve em uma pura tautologia. ${ }^{39}$ Assim H. Schnädelbach criticou o rompimento do círculo hermenêutico afirmando que não é possivel interpretar 'objetivamente' textos filosóficos excluindo a 'subjetividade' (e vice-versa) como nós, defendeu também a circularidade entre ambos. Nas palavras dele assumimos "o filosofar dialogicamente e a interpretação que procura interpretar objetivamente estão numa relação de tensão: este discurso

34 Hino homérico a Hermes, 14-5, apud Vernant, ibid., p. 153.

35 Id., 146-7, apud Vermant, ibid., p. 153.

36 Cf. nota 12: "o rosto triplo ou quádruplo do deus permite-lhe precisamente controlar todas as direçōes do espaço de uma só vez", apud Vemant, ibid., p. 153.

37 Id., ibid., p. 153-154.

38 CALVINO, Italo. Seis propostas para o próximo milênio: lições americanas. São Paulo: Companhia das Letras, 1998, p. 64. Antes dessa afirmação Italo confessa que rende um tributo especial ao deus do Olimpo, Hermes-Mercúrio, "o deus da comunicação e das mediaçōes, que sob o nome de Toth inventou a escrita, e que, segundo nos informa Jung em seus estudos sobre a simbologia alquímica, representa como 'espírito Mercúrio', também o principium individuationis".

39 Garagalza, op. cit., p. 115. 

mais compatíveis um com outro".40

Pode parecer estranho que falemos de uma estrutura da hermenêutica, não só por ser incomum, mas por parecer impróprio, uma vez que o termo estrutura parece referir-se especificamente a uma característica mais 'científica' que filosófica propriamente. Emerich Coreth, em sua obra Questões Fundamentais de Hermenêutica, é um dos raros pensadores que considera o 'círculo hermenêutico' como estrutura da hermenêutica. Nesta obra, o capítulo 2 tem por título "Essência e estrutura da compreensão", onde, além de explicitar o desenvolvimento histórico do 'círculo hermenêutico', tratou de quatro estruturas fundamentais da compreensão: 1. "estrutura de horizonte"; 41 2. "estrutura circular"; 3. "estrutura de diálogo";42 4. "estrutura da mediação". 43

40 Schnädelbach, op. cit., p. 46.

41 Nessa estrutura "a compreensão do singular é condicionada pela compreensão do todo, mas a compreensão do todo será mediada pela compreensão do conteúdo singular. Um elemento condiciona o outro e continua a se determinar a si mesmo no outro [...]. Trazemos sempre e necessariamente nosso próprio mundo de experiência e de compreensão como condição de nossa compreensão" (CORETH, E., Questões fundamentais de hermenêutica. São Paulo: EPU, Ed. da universidade de São Paulo, 1973, p. 101 e 102).

42 "Sua forma primitiva aparece no diálogo de homem para homem; entretanto, a mesma estrutura vale analogicamente de todas as outras formas da compreensão. Devemos abrir-nos ao outro, para entender o sentido de suas palavras. Com isso, tomamos, por um lado esse sentido dentro do próprio mundo de compreensão, a partir do qual o compreendemos; por outro lado, abrimos e ampliamos esse mundo pela percepção compreensiva de novos conteúdos e relações de sentido. No diálogo, mantemos nossa compreensão aberta, para enriquecê-la e corrigi-la. Isso, porém, só é possível olhando-se para a coisa que se há de compreender. A compreensão de um enunciado no diálogo somente se fará, se olharmos juntos para a coisa. A línguagem adquire seu sentido na coisa, mas esta não é dada sem mediação lingüística. Mostrada pelo enunciado lingüístico, nele é que se abre o sentido da coisa. Só quando me deixo mostrar pelo outro a coisa e abri-la a mim como a entende; quando ajusto contas com sua visão e interpretação da coisa, olhando-a eu mesmo; quando, portanto, conversamos sobre a mesma coisa, olhando-a eu mesmo; quando, portanto, conversamos sobre a mesma coisa, e nossos pontos de vista da mesma coisa, talvez divergentes, se encontram, se completam, se aprofundam e se corrigem, posso compreender seu enunciado - e, atrás disso, a 'ele' mesmo. A visão da coisa proporciona a compreensão do enunciado, o qual, por sua vez, possibilita uma compreensão mais plena da coisa. De novo, um elemento condiciona e medeia o outro. Compreensão lingüística e compreensão da coisa mostram uma relação mútua, na qual um elemento tanto condiciona como pressupōe o outro, determinando-o e desenvolvendo-se a si mesmo nele. Eis, de novo, um acontecimento de mediação circular ou que progride em forma de espiral" (Id., ibid., p. 102-103).

430 quarto aspecto constituinte da estrutura da compreensão é a estrutura da mediação, "própria da compreensão como um acontecimento vivo. Não é um sujeito puro e autônomo, e muito menos um sujeito absoluto, que está diante de uma objetividade pura, concebida isenta de um sujeito. O sujeito concreto já é em si mesmo condicionado e marcado por seu mundo e por sua histónia; nesse sentido, já é 'objeto' de seu mundo, antes de poder tomar-se 'sujeito' dele. [...] Nosso 'mundo' não é apenas um mundo determinado empiricamente e condicionado transcendentalmente, mas também, ao mesmo tempo, um mundo marcado historicamente e interpretado lingüisticamente, logo já muitas vezes 'mediado'. Constitui o horizonte no qual o homem concretamente se experimenta e se compreende. Nessa totalidade vigora de um modo insuprimivel o cruzamento de imediatez e mediação. Não só toda imediatez de uma concepção cognitiva e compreensiva é sempre já mediada, evidenciando-se por isso como 'imediatez mediada', mas também toda mediação se realiza por intermédio da imediatez, que a pressupõe, que a encerra em si e a desenvolve mediando: apresenta-se como 'mediação da imediatez'." (Id., ibid., p. 103-104). 
A partir de Gadamer pensamos que falta na obra de E. Coreth o exemplo do jogo como estrutura fundamental da compreensão. Parece-nos correto o fato de ele distinguir a 'estrutura circular' da 'estrutura do diálogo' como estruturas fundamentais da compreensão. Nós nos ateremos apenas à 'estrutura circular' pois consideramos esta de caráter mais especificamente 'ontológico' e aquele mais 'epistemológico'. 44

Quais são os aspectos constituintes e constituidores do círculo hermenêutico? Em que sentido podemos justificá-lo como estrutura da hermenêtica? Por que podemos afirmar que o círculo hermenêutico constitui parte importante da identidade da hermenêutica? Por que não é um 'círculo vicioso? É possível falar ou escrever sobre essa circularidade, como o "enquanto" da hermenêutica, uma vez que ela só existe ao acontecer? Essas são algumas das questões norteadoras e constituidoras da presente reflexão.

Lembremos que a preocupação fundamental da hermenêutica é com compreensão, que deriva do verbo 'compreender' que significa 'tomar junto', 'abranger com'. Ou, à maneira de Gadamer, "compreender, no sentido mais literal, significa pois, representar a causa de uma pessoa diante do tribunal - ou diante de quem quer que seja - sem restrições, estar em seu lugar". ${ }^{45}$ Toda compreensão é, para Coreth, "apreensão de um sentido". ${ }^{6}$ Embora importante, não desenvolveremos aqui a concepção, o significado e o sentido de 'sentido', ${ }^{47}$ desenvolvido por Heidegger ${ }^{48}$ e pela tradição hermenêutica.

44 Embora essa distinção tenha apenas validade metodológica.

45 "Verstehen im wörtlichsten Sinne heisst nämlich, eines anderen Sache vor Gericht - oder vor wem immer - ganz zu vertreten, für ihn zu stehen", H. G. GADAMER, Band. 10. Hermeneutik im Rückblick. 1995, p. 142.

Coreth, op. cit., p. 45.

47 "O circulo da compreensâo pertence à estrutura do sentido" (§ 32, HEIDEGGER, M., Ser e Tempo. Parte I. Petrópolis: Vozes, 1989).

48 E. Coreth faz então a mesma pergunta que fazemos: "o que significa aqui 'sentido'?" e retoma a resposta de Heidegger a essa questão: “"quando o sendo intramundano se descobre com o ser da existência, isto é, quando chegou à compreensão, dizemos que tem sentido'. Quando, por conseguinte, na realização da existência - como ser-no-mundo, que compreende - surge algo no horizonte da compreensão, ou seja, entra no 'mundo' e se toma compreendido por ele, tem 'sentido'. 'Mas o que é compreensivo, estritamente falando, não é o sentido, mas o sendo, respectivamente, o ser. O articulável na abertura compreensiva, é o que chamamos sentido... Sentido é o... para onde do projeto, a partir do qual uma-coisa-como-uma-coisa se torna compreensivel'. 'Sentido é um existencial da existência e não uma propriedade inerente ao sendo [...]. Somente a existência 'tem' sentido, enquanto a abertura do ser-no-mundo pode 'encher-se' pelo ser descoberto nele. Logo, só a existência pode ser ou não ser significativa: seu ser próprio e o sendo que com ele se sabe pode permanecer apropriado na compreensão ou recusado à incompreensão'. Isso mostra que o 'sentido' se subordina à compreensão como aquilo 'em que' alguma coisa é compreendida. Abre se no todo do projeto de sentido da existência, a partir da qual - dentro da totalidade do sentido atirada pela existência - se mostra significativa ou não. $\mathrm{O}$ decisivo, porém, é que 'alguma coisa como alguma coisa' seja compreendida, e essa compreensão se funde num projeto prévio de uma totalidade de sentido" (Coreth, ibid., p. 85). A propósito desse tema, ver texto do prof. E. Stein, "O logos hermenêutico. Estrutura do sentido e sentido da estrutura" (In: Aproximações sobre Hermenêutica, p. 21-33); ver também sua obra Instauração do sentido. 
A fim de dar uma resposta aos desafios que a própria história põe ao círculo hermenêutico e às nossas questöes utilizaremos a reflexão de H. G. Gadamer ${ }^{49}$ uma vez que ele refaz seu nascimento e desenvolvimento históricos. No conjunto dos seus dez volumes encontramos dois lugares onde desenvolveu a concepção de círculo hermenêutico: em Verdade e Método I (=VMI), II ${ }^{\mathrm{a}}$ Parte e em Verdade e Método II (=VMII) num ensaio intitulado Sobre o círculo da compreensão. Analisaremos e explicitaremos o segundo o qual constitui uma ampliação e aprofundamento do primeiro.

Em ambos os lugares, a intenção de Gadamer é a mesma, ou seja, o desenvolvimento da concepção de círculo hermenêutico para combater a ingenuidade do historicismo mostrando como é que se constitui verdadeiramente a 'ciência' da história, não como ciência no sentido moderno, mas como um acontecimento, como uma experiência. Ou seja, como, "uma vez liberada das inibições ontológicas do conceito de objetividade da ciência, a hermenêutica pôde fazer jus à historicidade da compreensão". 50

Gadamer lembra que "a regra hermenêutica de que o todo deve entender-se desde o individual, e o individual desde o todo" constitui um movimento circular. Ilustrativo disso é a aprendizagem de uma língua estrangeira. Nessa experiência "o movimento da compreensão discorre assim do todo à parte e de novo ao todo. A tarefa é ampliar em círculos concêntricos a unidade do sentido compreendido. A confluência de todos os detalhes no todo é o critério para a retidão da compreensão. A falta de tal confluência significa o fracasso da compreensão". 51

F. Schleiermacher foi o primeiro hermeneuta que desenvolveu explicitamente a concepção de 'círculo hermenêutico', para quem, nele se move toda a compreensão. Para ele há uma relação recíproca do singular e do todo de que esse singular faz parte. ${ }^{52}$

Gadamer retoma a concepção de círculo hermenêutico de Schleiermacher afirmando que a tarefa da hermenêutica não consiste em chegar a uma "comunhão misteriosa das almas" e que é impossível chegar à "esfera anímica" do autor, mas se trata de "criar um acordo que não existia ou era incorreto". 53 Ou seja, Schleiermacher ficou preso ao metodologicismo hermenêutico, preocupou-se mais

49 Ao tratar da 'liberação' da questão da verdade desde a experiência da arte Gadamer explicita 'a ontologia da obra de arte e seu significado hermenêutico' mostrando o jogo como 'fio condutor da explicação ontológica'. Infelizmente não abordaremos aqui esse outro aspecto que consideramos 'estrutural-metódico' da hermenêutica, mas nos concentraremos apenas no conhecido 'círculo hermenêutico'. Na obra Verdade e método Ié conhecida a posição de Gadamer que se trata de explicitar a verdade contra o método das ciências naturais. Pensamos que Gadamer desenvolveu um método, constituinte e constituidor da estrutura da hermenêutica filosófica, representado pelo 'jogo' (I parte do VMI), 'circulo hermenêutico' (II parte do VMI) e 'diálogo'(III parte do VMI). Num certo sentido pensamos que as duas primeiras partes têm um caráter ainda 'epistemológico-didático', mas constitui o modo de ser da hermenêutica. Na última parte o caráter é mais especificamente 'ontológico'.

50 GADAMER, H. G., Verdade e método I. Petrópolis: Vozes, 1997, p. 400.

51 GADAMER, H. G., Verdad y metodo II. Salamanca: Sigueme, 1992, p. 63.

52 Em nota de rodapé (n. 17) Coreth afirma: "em toda parte, o saber perfeito encontra-se neste circulo aparente, que todo particular só pode ser compreendido pelo geral, de que faz parte, e vice-versa"

Gadamer, VMII. p. 64. 
com o significado apreensível e explicável pelo círculo hermenêutico que pela compreensão do sentido que o mesmo possibilita.

De acordo com E. Coreth, foi Heidegger o primeiro, em Ser e Tempo, a explicitar e justificar, por princípio, "o círculo hermenêutico como lei básica da compreensão". Desde Schleiermacher até ele "concebera-se a estrutura circular entre o particular e o todo somente como relação entre o conteúdo 'objetivo' de sentido e suas relações de sentido num contexto igualmente 'objetivo'; nessa acepção, tem-se de compreender o particular pelo geral e o geral por seus elementos particulares". Em Heidegger esse problema é desenvolvido de modo que o círculo deixa de ser simplesmente metodológico (hermenêutica como uma arte, ou até ciência, universal de compreensão do sentido) e passa a ser 'ontológico' (hermenêutica como o modo de constituição do sentido por um sujeito inserido numa tradição). Ou seja, Heidegger introduziu no círculo hermenêutico o "sujeito mesmo que compreende" que "toma sempre consigo o todo de seu mundo, a partir do qual realiza a projeção do sentido e no qual somente se abre o conteúdo individual em seu sentido". 54 Ou, nas palavras de Weinsheimer, "toda compreensão é autocompreensão", o que Gadamer assumiu e Heidegger "descreve não o que a interpretação deve ser e menos ainda o que não deve ser, mas ao invés, o que a interpretação sempre é". 55

Gadamer quer pensar as implicações que têm o fato de Heidegger derivar a estrutura circular da compreensão a partir da temporalidade do Dasein. Poderiam, como diz Gadamer, "consistir em que a autocompreensão da compreensão exercida constantemente fosse corrigida e depurada de adaptações inadequadas; um processo que mormente se optimalizaria por meio da arte do compreender". ${ }^{56}$

Heidegger e Gadamer, preocupados com as condições de possibilidade do sentido, não apenas com as condições de possibilidade do conhecimento como seus antecessores, ontologizaram o círculo hermenêutico e desde então ele não pode mais ser considerado metodológico ou lógico. Enquanto a ontologia ingênua trata dos objetos, supostamente, reais, Gadamer desenvolveu uma ontologia fundamental (existencial) não fundacional. E o círculo hermenêutico constitui uma das possibilidades de mostrá-la.

Para Gadamer, a "estrutura circular da compreensão adquire com a análise existencial de Heidegger seu verdadeiro significado", pois "o círculo não deve degenerar em círculo vicioso, mesmo que este seja tolerado. Há nele uma possibilidade positiva para o conhecimento mais originário, possibilidade que só se alcança realmente uma vez que a interpretação compreendeu que sua tarefa primeira, permanente e última consiste em não deixar que a experiência prévia, a previsão e a antecipação sejam suplantadas por ocorrências e noções vulgares, e assegurar o tema científico em sua elaboração desde as coisas mesmas". ${ }^{57}$

54 Coreth, op, cit., p. 83.

55 "All understanding is self-understanding - this is Heidegger's version of the hermeneutic circle, and it is Gadamer's as well. It describes not what interpretation should be, still less what it should not be, but instead what interpretation always is" (WEINSHEIMER, J. C. Gadamer's hermeneutics: a reading of 'Truth and method'. New Haven and London: Yale University Press, 1985, p. 166).

56 Gadamer, VMI, p. 400-401.

57 Id., VMII, p. 64-65. A propósito disso ver "A questão da boa circularidade" na obra de E. Stein Seis estudos sobre 'Ser e T'mpo'," 
Um dos nossos interesses é mostrar que o círculo hermenêutico é uma das formas de expressar a 'estrutura' da hermenêutica. Além disso, que o conhecimento científico pode ser vicioso por querer confirmar suas hipóteses, mas o saber hermenêutico é positivo, muito mais que confirmação ou rejeição de hipóteses, enquanto 'conhecimento mais originário', ou seja, mais fundamental, mais ontológico, menos restritivo, assegurando, como diz o próprio Heidegger, "o tema científico na elaboração desses conceitos a partir da coisa, ela mesma" e não de um sujeito, separado do objeto, que o determinaria de modo racional e asséptico. Para nós o círculo hermenêutico é 'ontológico' e 'positivo', não vicioso. Em nota da página do VMI, Gadamer afirma que "contra o discurso do 'círculo hermenêutico', a objeção levantada desconhece, do ponto de vista lógico, que aqui não se está provocando uma exigência de prova científica, mas que se trata de uma metáfora lógica, conhecida no âmbito da retórica desde Schleiermacher". ${ }^{5}$

Heidegger não pretendeu demonstrar a circularidade da compreensão ou conceitualizá-la, mas mostrar seu sentido ontologicamente positivo. Ou seja, "toda interpretação correta deve guardar-se da arbitrariedade das ocorrências e da limitação dos hábitos mentais inadvertidos, e se fixar "nas coisas mesmas"'. ${ }^{59}$ A propósito, lembramos aqui a afirmação de Gadamer: "o que está em questão não é o que nós fazemos, o que nós deveríamos fazer, mas o que, ultrapassando nosso querer e fazer, nos sobrevém, ou nos acontece". 60 Esse reger-se "pela coisa mesma" é a "tarefa primeira, permanente e última" da compreensão que é preciso para evitar os desvios que espreitam constantemente o intérprete. Quem propõese a "compreender um texto faz sempre um projeto. Antecipa um sentido do conjunto uma vez que aparece um primeiro sentido no texto. Este primeiro sentido se manifesta por sua vez porque lemos já o texto com certas expectativas sobre um determinado sentido. A compreensão do texto consiste na elaboração de tal projeto, sempre sujeito a revisão como resultado de um aprofundamento do sentido". ${ }^{61}$

Nisso constitui-se o círculo hermenêutico como um "enquanto" constituidor do sentido, pois "que cada revisão do projeto pode desembocar em um novo projeto de sentido" que os projetos em questão "podem contribuir conjuntamente a uma reelaboração até fixar com mais claridade a unidade do sentido; que a interpretação começa com pré-conceitos que são substituídos por conceitos mais adequados". Para Heidegger é esse "constante re-desenho que constitui o movimento da compreensão e da interpretação". Desse modo, quem procura "compreender está exposto a confundir-se pelas opiniões prévias" e que, por esse motivo, "é dever permanente da compreensão elaborar os esquemas corretos e adequados, isto é, aventurar hipóteses que fará confrontar 'com as coisas'. Não há aqui outra 'objetividade' que a da elaboração da opinião prévia para confrontá-la (com ou-

\footnotetext{
58 Gadamer, VMI., n. 188, p. 401. A propósito do poder e valor da metáfora, ver Metaphors We Live By, George Lakoff and Mark Johnson. Chicago and London: The University of Chicago Press, 1980; More than Cool Reason: A Field Guide to Poetic Metaphor, George Lakoff and Mark Turner. Chicago and London: The University of Chicago Press, 1989.

Id.. VMII, p. 65

60 Id., VMI, p. 14.

61 Id., VMII, p. 65.
} 
tras). Tem seu sentido o afirmar que o intérprete não aborda o 'texto' desde sua instalação no pré-juízo prévio; mas põe expressamente à prova o pré-juízo em que está instalado, isto é, põe à prova sua origem e validez". ${ }^{2}$ Essa é a 'objetividade' própria da hermenêutica.

Assim, ao escutar alguém ou realizar uma leitura, não se trata de não levar em conta os próprios pré-juizos sobre o conteúdo ou negar suas próprias opiniões, mas estar aberto à opinião do outro ou do texto, o que implica relacioná-los com os próprios juízos ou opiniões. Dentro da diversidade de opiniões, que dá uma aparência de arbitrariedade, nem tudo é possível. Quem procura compreender, para Gadamer, "não se abandonará sem mais ao azar da própria opinião para desouvir a opinião do texto o mais conseqüente e obstinadamente possivel [...] até que essa opinião se faça inevitável e invalide a presumida compreensão. O que tenciona compreender um texto está disposto a deixar que o texto lhe diga algo. Por isso, uma consciência formada hermeneuticamente deve estar disposta a acolher a alteridade do texto. Porém, tal receptividade não supõe a 'neutralidade' nem a autocensura, senão que implica a apropriação seletiva das próprias opiniões e pré-juizos. É preciso prevenir-se das próprias prevenções para que o texto mesmo apareça em sua alteridade e faça valer sua verdade real contra a própria opinião". ${ }^{63}$ Isso nós designamos como a 'objetividade' da circularidade hermenêutica que é estrutural. Essa 'objetividade' não exclui a 'subjetividade' nem a objetividade científica. No círculo hermenêutico "uma compreensão guiada por uma intenção metodológica não buscará confirmar simplesmente suas antecipações, senão que intentará tomar consciência delas para controlá-las e obter assim a reta compreensão a partir das coisas mesmas", 64 e nisso consistiria um aspecto da 'objetividade' da hermenêutica conforme nossa opinião. É uma 'objetividade' não rígida, nem dogmática ou fechada das ciências.

A crítica ao formalismo do círculo hermenêutico que pretendia culminar no 'ato divinitório' pode ser realizado de outra maneira. O círculo hermenêutico, em Schleiermacher, teria um término, portanto, implodir-se-ia no momento que o intérprete pudesse acessar ao 'sentido' subjacente ao texto que o próprio autor desconhecia. Na concepção de Heidegger e Gadamer há uma circularidade 'eterna', uma 'inesgotabilidade de sentido'. Heidegger reconhece que "a compreensão do texto está determinada permanentemente pelo movimento antecipatório da pré-compreensão". Nossa tarefa consiste em "descobrir as próprias prevenções e pré-juízos e realizar a compreensão desde a consciência histórica, de forma que o detectar o historicamente diferente e a aplicação dos métodos históricos não se limitem a uma confirmação das próprias hipóteses ou antecipações". ${ }^{65}$

Para Gadamer há uma pertença prévia do sujeito à tradição no comportamento histórico-hermenêutico. Pois quem empreende a tarefa da compreensão "está ligado à coisa transmitida e mantém ou adquire um nexo com a tradição da qual fala o texto transmitido". Por outro lado, a consciência hermenêutica sabe

62 Id., ibid., p. 65-66.

63 Id., ibid., p. 66.

64 Id., ibid., p. 66.

65 Id., ibid., p. 67. 
que essa pertença, essa ligação à 'coisa' não é uma coincidência óbvia. Acontece numa "polaridade entre familiaridade e estranheza na qual se baseia a tarefa hermenêutica". Nessa circularidade o sentido é 'explicitado' e não 'extraído'. Ou como Gadamer expressa de outra maneira, "o posto entre estranheza e familiaridade, que ocupa para nós a tradição, é, pois, o inter entre a objetividade distante contemplada na história e a pertença a uma tradição. Nesse inter está o verdadeiro lugar da hermenêutica", ${ }^{66}$ que nós preferimos chamar de "enquanto".

Como afirmamos anteriormente, fundamentalmente, Gadamer está às voltas com a ingenuidade do historicismo. A estrutura circular mostra, muito bem, a fraqueza deste. Sua pretensão não foi propriamente a de 'definir' ou mostrar a 'identidade' do círculo hermenêutico, tanto no VMI como no VMII, mas explicitar que há um círculo entre quem compreende e o que é compreendido. Nas palavras do próprio Gadamer, "o verdadeiro objeto histórico não é um objeto, senão a unidade do um e o outro, uma relação na qual consiste tanto a realidade da história como a realidade da compreensão histórica. Uma hermenêutica correta terá que mostrar na compreensão mesma esta autêntica realidade da história. Compreender é um processo da história efetiva, e se poderia demonstrar que é a lingüisticidade própria a toda compreensão na qual o acontecer hermenêutico realiza seu caminho".67

\section{Por uma compreensão hermenêutica do mito de Hermes; sobre o círculo hermenêutico como estrutura, o "enquanto" da hermenêutica filosófica}

\subsection{Por uma compreensão hermenêutica do mito de Hermes}

Lembramos que um dos nossos propósitos iniciais foi de justificar a validade e a identidade da hermenêutica filosófica. Para isso nos utilizamos de duas dimensões da hermenêutica: sua origem mítico-etimológica e o círculo hermenêutico como estrutura da mesma, seu "enquanto".

Explicitaremos a relação entre essas duas faces da hermenêutica que constituem, para nós, uma unidade. Algumas das funções e das características do deus Hermes encontramo-las no círculo hermenêutico e vice-versa.

O deus Hermes, ao nascer, desligou-se das "faixas" que o prendiam, o que constitui uma demonstração do seu poder de ligar e desligar; hermeneuticamente diríamos poder de estabelecer a ligação ou desligamento entre a pré-compreensão e a compreensão, o pré-juízo e o juízo, o singular e o todo, indo e vindo de uma à outra margem, constituindo a 'terceira margem do rio'.

Conforme Teágenes, Hermes era a forma divina de nomear a linguagem e considerado por outros o criador da palavra e das línguas. Ora, a hermenêutica tem a linguagem como seu meio universal de reflexão na concepção de Gadamer. Em Hermes, deus da linguagem, como na hermenêutica, a linguagem, além de ser

66 Id., ibid., p. 68.

67 "Verstehen ist ein wirkungsgeschichtlicher Vorgang, und es liesse sich nachweisen, dass es die allem Verstehen zukommende Sprachlichkeit ist, in der das hermeneutische Geschehen seine Bahn zieht", GADAMER, H. G., Band. 2 - Hermeneutik: Wahrheit und Methode -2. 1993, p. 65. 
condição, caminho é instauradora de sentido, mais que uma simples possibilidade descritiva das coisas. Linguagem como um acontecer que é muito mais que análise de proposições. Para Luis Garagalza, Hermes é o deus da linguagem "e, muito especialmente, da linguagem simbólica". ${ }^{8}$ Ele comenta ainda que Hermes é capaz de 'co-implicar opostos', "é o que ajuda aos homens na busca de sentido". Simbolizando o símbolo "que por sua vez simboliza o sentido, Hermes, espécie de símbolo à $2^{\mathrm{a}}$ potência, representa a função simbólica em ato, a poesia, a criatividade humana que, infligindo uma ferida metafórica às coisas, permite que estas soltem seu aroma (sentido)". ${ }^{9} \mathrm{E}$ na hermenêutica a linguagem pressuposta é simbólica, muito mais que designativa, unívoca.

Podemos interpretar a possibilidade de Hermes de não se ver obrigado a dizer a "verdade por inteiro" como uma componente fundamental da hermenêutica. É impossível satisfazer plenamente hoje a pergunta de Pilatos: "o que é a verdade?". O deus Hermes já apontara a impossibilidade de identificar a certeza com a verdade e a impossibilidade de expressá-la por 'inteiro', ou seja, como algo 'fixo', 'absoluto', mas como um acontecimento, sempre parcial da verdade, da totalidade.

A própria identidade de Hermes, complexa, com muitos atributos, faces e funções, como o que tem "rosto triplo ou quádruplo", dificulta dizer quem ele é. Podemos ver o mesmo no círculo hermenêutico ao afirmar que ele, como estrutura da hermenêutica, é expressável pelo termo "enquanto", entre o dito e o não-dito, entre a pré-compreensão e a compreensão, entre o 'sujeito' e o 'objeto'. Dificuldade semelhante encontramos na tentativa de definir o que é hermenêutica, $p$. ex., pelos títulos que recebe 'traços fundamentais', 'questões fundamentais', 'aproximações'. E ao mesmo tempo sua mais alta capacidade criativa (como ocorre com o mito, p. ex.).

Hermes, o menos 'olimpico dos imortais' e companheiro dos homens, tem um enorme apreço por estes. Ora, a hermenêutica tornou-se, no âmbito da finitude humana, o conhecimento apropriado a estes levando-a a sério com seus préconceitos e limites em busca de sua correção e aprofundamento sem a pretensão de eternizá-lo.

Hermes era o deus que circulava, como psicopompo, nos três níveis, ctônico ao telúrico e vice-versa apontando para outra caraterística da hermenêutica que, como discurso aberto, ou ontologia indireta (nas palavras de J. Gauvin), permite a circulação entre o dizivel e o indizivel, o temporal e o eterno, o conhecido e o desconhecido.

A relação mais conhecida entre a mitologia e a hermenêutica é a que se refere à tarefa de Hermes, ou seja, a de ser o intérprete, o transmissor da vontade dos deuses para os mortais, o que é possível representar, p. ex., pelo termo alemão übersetzen, "levar de uma margem à outra [...]".

Como Hermes, que teve de ser o anunciador de más notícias, p. ex., a Hércules para ser vendido como escravo, cabe à hermenêutica a ingrata e importante tarefa de mostrar e denunciar os pressupostos postos nas ciências, na política, no conhecimento. O que pode abalar a segurança, a solidez do conhecimento, a 'or-

68 Garagalza, op. cit., p. 116.

69 Id., ibid., p. 117. 
dem e progresso' de uma dada realidade. Coube também a Hermes a grata missão de conduzir Psiqué ao Olimpo para se casar com Eros, e à hermenêutica a tarefa de levar as pessoas ao entendimento, à boa convivência pela explicitação dos préconceitos, do que foi reprimido, do não dito.

Opostamente a Héstia, Hermes representa o exterior, a abertura, a mobilidade, o contato entre os homens. A hermenêutica, como vimos pelo círculo hermenêutico, pressupõe a abertura fundamental à coisa, às pessoas e está em constante e eterno movimento.

Para Hermes não há fechadura que resista à sua entrada, e sendo representado à porta das casas, representa a circularidade compreensiva que não estanca a emergência, a explicitação e a constituição do sentido.

Hermes, sendo aquele que não "se pode prever, nem reter", como um "ser desgarrado, fragmentário, sem personalidade própria e definida" na expressão de L. Garagalza, ${ }^{70}$ representa muito bem a hermenêutica que não retém o acontecer e o experienciar do conhecimento humano. Na circularidade hermenêutica ocorre uma experiência que é sempre única, irrepetível e que, não cabendo em conceitos, não pode ser retida, voluntária ou racionalmente.

\subsection{Sobre o "círculo hermenêutico" como estrutura, o "enquanto" da hermenêutica filosófica}

Não é possível separar a interpretação 'objetivamente-determinada', p. ex., daquela que a faz de maneira 'subjetivamente-refletida', pois ao modo do diálogo, como afirma H. Schnädelbach "estão o repensar de idéias do outro e o pensar próprio que, na verdade, é um continuar a pensar, sempre já junto; quem quer dissolver essa relação de um ao outro termina com o diálogo". ${ }^{71}$

Com o círculo hermenêutico é possível superar a clássica dicotomia: explicar e compreender ou interpretar e compreender, uma vez que ele mostra que há uma compreensão originária, anterior ao momento temático, que nós denominamos 'ontológico' - que o círculo hermenêutico permite explicitar. A esquizofrenia filosófica entre Sujeito e Objeto não é resolvida pela eliminação ou supremacia de um dos 'pólos', mas pelo reconhecimento da existência de ambos numa circularidade. Trata-se, pois, na filosofia, não da eliminação de um tipo ou outro de interpretação, mas de uma relação adequada entre ambas.

\section{Sobre a estrutura do círculo hermenêutico da hermenêutica}

De acordo com E. Coreth, Gadamer mostrou que, para Heidegger, o aspecto fundamental da compreensão, "o que é expressamente compreendido, tem a estrutura de alguma-coisa-como-alguma-coisa", e designa-a "estrutura-como". De outra maneira, a estrutura como pertence à "constituição existencial a priori da

70 Id., ibid., p. 116.

71 "Beides kann man aber nicht voneinander trennen, denn im Dialogs ind das Nach-Denken fremder Gedanken und das eigene Nach-denken, das in Wahrheit ein Weiterdenken ist, immer schon zusammem; wer dieses Ineinander auflösen will, beendet den Dialog"' (Schnädelbach, op. cit., p. 47). 
compreensão".72 Nós preferimos utilizar a expressão "enquanto" - termo que indica movimento, inapreensibilidade (próprios de Hermes) e por outro lado indica um 'algo', ainda não dito a se dizer - para designar o 'como' desenvolvido por Heidegger.

Com acerto e razão Heidegger referiu-se a uma compreensão original precedente a toda dualidade entre esclarecer e compreender que possibilita toda interpretação. Também concordamos com a designação disso pela 'estrutura-como', que não é própria somente do enunciado explícito, do dito, mas precede-o, como o não-dito. E "essa estrutura se funda na finitude essencial do conhecimento e compreensão humanas". ${ }^{73}$ Ou seja, o círculo hermenêutico é o "enquanto" da compreensão, isto é, uma das formas de expressar a estrutura da hermenêutica filosófica (junto com o ‘jogo', com o 'diálogo' que não pudemos desenvolver aqui).

\section{Círculo hermenêutico não é vicioso porque [...]}

O círculo é vicioso quando pretende provar o que pressupõe e não tematiza seus próprios pressupostos. Ora, as provas científicas, apresentando uma hipótese, pretendem provar um pressuposto não posto que, após ser 'comprovada', converte-se em tese e assim justifica-se como ciência. Nesse caso, toda interpretação histórica é banida. Coloca-se então a seguinte alternativa: "ou se consegue evitar o círculo e alcançar uma ciência da história que seja uma ciência puramente objetiva, tão independente portanto do ponto de vista subjetivo do observador quanto a ciência natural supostamente o é; ou, se o círculo da compreensão não pode ser evitado, não há história como ciência estrita, e até, caso o círculo se demonstrasse como estrutura geral de todo conhecimento, mesmo do científico, não haveria de modo algum algo que fosse ciência estrita, ciência sem pressupostos". ${ }^{74}$ Assim como não há ciência da história, rigorosamente falando, não há também círculo hermenêutico. Para Heidegger, ver o círculo viciosamente como uma imperfeição significa não compreender fundamentalmente a compreensão. Por isso que "0 decisivo não é sair do círculo, mas entrar de maneira correta", ou seja, nele encontramos "uma possibilidade positiva de conhecimento mais original". Entrar bem significa mostrar os próprios pressupostos explicitando a compreensão de si e do mundo que o sujeito carrega consigo, o que precede todo conhecimento temático, o dito, a ciência particular. ${ }^{75}$ Com o círculo hermenêutico apontamos a dimensão pré-reflexiva que denominamos ontológica.

Afirmá-lo como vicioso significa vê-lo unilateralmente, pois consideramos a pré-compreensão como condição, não como empecilho, do ato compreensivo. Toda nova compreensão é inserida em nosso mundo compreensivo, enriquecendo

72 Coreth, op. cit., p. 84. Mais adiante Coreth acrescenta o seguinte: "A coisa que vem a nosso encontro abre-se primeiro principalmente numa 'totalidade da situação'; apreendemo-la e compreendemo-la originalmente num contexto de sentido, numa totalidade de significação. Isto, porém, quer dizer que toda compreensão se baseia num 'olhar' anterior, numa 'antecipação' projetora, isto é, no projeto de uma totalidade de sentido, dentro do qual o particular se revela primeiramente em seu sentido" (p. 84-85).

73 Id., ibid., p. 89.

74 Id., ibid., p. 85-86.

75 Id., ibid., p. 86-87. 
e aprofundando nossa pré-compreensão. Esta é, "por essência 'aberta' e, por conseguinte, deve ser mantida aberta para uma compreensão também daquilo que não está indicado pela pré-compreensão anterior, não podendo ser esperado nem previsto a partir dela, e que forçosamente não se insere nela, mas a arrebenta e assim a amplia, abrindo novos horizonte". ${ }^{76}$

$\mathrm{Na}$ lógica o círculo vicioso ocorre quando se pressupõe o que deve ser provado ou quando o pressuposto, o 'donde' da prova permanece pressuposto, sem ter sido supresso ou posto em questão; nele se baseia o valor do resultado". Já no círculo hermenêutico a "pré-compreensão abre uma primeira via de acesso à coisa, mas não permanece numa validez indiscutível, enriquecida ou retificada que é por todos os novos conhecimentos adquiridos e todas as novas compreensões de sentido". Não há uma derivação lógica da compreensão da coisa a partir da précompreensão, mas ela se funda no 'mostrar-se' da coisa mesma. Decorre disso que "a pré-compreensão não é a pressuposição lógica de um pensamento demonstrativo, mas sim condiçäo da possibilidade da compreensão que abre o sentido. Aqui não há nenhum círculo lógico, mas apenas um círculo - hermenêutico de estrutura completamente diversa. Além disso, estritamente falando, não é um círculo no sentido de uma circunferência que se fecha em si mesma, mas antes para permanecer na imagem - um acontecimento em espiral, na qual um elemento continua dialeticamente a se determinar e formar no outro", 77 sem um fim ou finalidade pré-determinados. Nesse caso, diferentemente do círculo vicioso, "o todo do mundo da compreensão é enriquecido e aprofundado por toda compreensão novamente adquirida, e justamente por isso possibilita uma compreensão mais plena e mais profunda do conteúdo singular de sentido". ${ }^{78}$

E. Coreth, ao tratar especificamente da estrutura circular da compreensão afirma que toda compreensão realiza-se sob o pano de fundo da pré-compreensão "que procede de nosso próprio mundo de experiência e de compreensão e é formada por ela". A pré-compreensão não é uma grandeza definidamente fixa, mas continua formando-se, alargando-se com o progresso da compreensão. Desse modo, a pré-compreensão deve estar aberta à 'coisa mesma'. De forma resumida E. Coreth concebe o círculo hermenêutico assim: "a compreensão se move numa dialética entre a pré-compreensão e compreensão da coisa, num acontecimento que progride circularmente, ou melhor, em forma de espiral, na medida em que um elemento pressupõe o outro e ao mesmo tempo faz com que ele vá adiante; um medeia o outro, mas continua a determinar-se por ele". ${ }^{79}$

\section{Crítica a Gadamer}

Para Gadamer a '“pré-compreensão' torna-se o 'pré-juízo', cuja significação positiva ele procura salientar'. A tentativa de Gadamer de valorizar o conceito

76 Id., ibid., p. 88-89.

77 Id., ibid., p. 90.

78 Id., ibid., p. 90.

79 Id., ibid., p. 102. Em nossa opinião essa é uma metáfora feliz para expressar a circularidade hermenêtica, uma vez que Ulisses, embora seja o mesmo que tenha saído e voltado para casa, é e näo mais o mesmo. 
quase não surtiu efeito", afirma E. Coreth; ${ }^{80}$ com o que concordamos, pois nem toda compreensão já foi ou é possivel ser conceitualizada. Pensamos que Heidegger, ao mostrar a circularidade entre a pré-compreensão ${ }^{81}$ e a compreensão não restringe o alcance do círculo hermenêutico como o faz Gadamer ao utilizar o termo pré-conceito.

Se por um lado, com mérito, Gadamer quis mostrar a circularidade envolvida no processo de 'conhecimento histórico' (e consegue muito bem mostrar a ingênua pretensão do historicismo), por outro lado, temos a impressão que o círculo hermenêutico foi instrumentalizado por Gadamer. Isto é, utilizou-o mais para mostrar a fraqueza do historicismo, que para justificá-lo como estrutura, como "enquanto" da hermenêutica filosófica. Na I⿳亠 Parte do VMI, Gadamer fez algo similar com o 'jogo como fio condutor da explicação ontológica' para mostrar como se dá a experiência da arte, com o que não concordamos plenamente, embora seja coerente com seu propósito de não conceitualizar a hermenêutica. Para nós, o 'modelo', a estrutura do jogo representa e constitui não apenas um método explicativo de como ocorre a experiência da arte, mas constitui-se como estrutura da hermenêutica.

\section{Conclusão}

A dificuldade que a hermenêutica tem de mostrar e afirmar sua estrutura pode ser comparada ao exemplo que Adorno apresenta da imagem produzida pelo fenômeno do fogo de artifício, considerado "efêmero e enquanto divertimento vazio". ${ }^{82}$ Imagem brilhante, que aparece e desaparece, sem a consistência que exigem as ciências dos seus objetos. Hermes é assim também, aparece e desaparece e nesse ínterim fugidio, próprio da experiência finita humana, existe um saber que pode ser apreensível parcialmente. Ou seja, estamos um pouco mais adiante do que estávamos no começo desse texto. Quisemos trabalhar o problema da identidade (o que é rigorosamente uma contradição!) da hermenêutica. Concluímos que ela continua um problema e se constitui como tal no sentido que nunca haverá uma solução, uma resposta que possa esgotá-la.

A face ambigua, relativista da hermenêutica é seu tendão de Aquiles para aqueles que se movem no terreno da lógica, da matemática apenas. Mas, movendo-se no terreno do saber humano ela não chegará a um conhecimento definitivo, absoluto, eterno que, talvez, deseja. A atividade filosófica está às voltas não apenas com o projeto, com o conceito, mas com a relação, com "enquanto" ante o pré-projeto, o pré-conceito que, embora não seja absoluto, é filosófico. Como afirmou E. Fink, "a obra da sabedoria humana assemelha-se ao trabalho de Sísifo", ${ }^{83}$

80 Id., ibid., p. 87.

81 A pré-compreensão, considerada estaticamente e fechada, suprimiria a possibilidade estrutural dialógica, constituinte e constituidora da compreensão, uma vez que essa "se mostra principalmente na compreensão pessoal do diálogo inter-humano" (Id., ibid., p. 89).

82 "O fenômeno do fogo de artificio que, por causa do seu caráter efêmero e enquanto divertimento vazio, dificilmente foi julgado digno de consideração teórico [...]" (ADORNO, T., Teoria estética. Sảo Paulo: Martins Fontes, 1970, p. 98.

83 FINK, E. Le Jeu comme symbole de monde. Paris: Minuit, 1966, p. 12. 
ou seja, reconhecer a identidade da hermenêutica com seus 'múltiplos rostos' significa assumir a filosofia como "uma possibilidade finita do homem finito". ${ }^{84} \mathrm{De}$ outra maneira, de acordo com E. Stein; "há uma ambigüidade fundamental no homem e por haver esta ambigüidade fundamental é que estamos condenados à hermenêutica". 85 O difícil e o mais importante para a hermenêutica filosófica, para nós, é não preencher ou não eliminar o espaço Sujeito-Objeto, pré-conceito e conceito, intérprete e texto e aceitar que há um movimento, do ir e vir, do subir e descer, não teleologicamente pré-determinado que designamos "enquanto", que é a possibilidade inesgotável da própria filosofia. ${ }^{86}$ Fazendo isso ela respeita a subjetividade humana libertando-a da inexorabilidade fáctica ou histórica.

A hermenêutica não é um 'martelo' para estraçalhar sistemas complexos para então poder assimilá-los, não é também uma 'serra' para decompor em partes menores um todo e desse modo torná-lo compreensível, nem muito menos uma 'broca' para penetrar e extrair o sentido de textos considerados clássicos. Por meio de nossa investigação mítico-etimológica e explicitação do círculo hermenêutico mostramos que a hermenêutica é um modo de ser próprio da compreensão e saber humanos, uma vez que a filosofia não trabalha diretamente com objetos, mas sobre as condições de possibilidade dos enunciados verdadeiros e/ou falsos.

Dessa maneira, a filosofia é sempre uma espécie de espelhamento de nossa realidade. Na reconstrução hermenêutica do objeto, por exemplo, somos sempre co-pertencentes e relacionados com eles. A tarefa hermenêutica não se refere apenas à interpretação do texto, mas à compreensão, ao 'estar junto de' (objetos, pessoas, mundo).

Com o círculo hermenêutico destruímos a solidez aparente das ciências, pois a compreensão trabalha com o sentido que é sempre inesgotável, não com o que é catalogável (o que é tarefa da ciência). Já a hermenêutica, como o vemos em sua circularidade, mostra a impossibilidade do domínio sobre seu acontecer, de determinar as condições de possibilidade da compreensão que são sempre históricos.

Considerando tudo isto, o círculo hermenêutico como o "enquanto", não estariam os hermeneutas em busca de algo que não existe (mesmo que esse algo receba o nome de sentido)? De fato, a hermenêutica talvez não seja um conhecimento por não possuir um objeto definido. Ela propriamente não é conhecimento, mas faculta-o e que por isso é mais que simples conhecimento. Na expressão de Boeck, "é conhecimento do conhecido" que não é simples reconhecimento em Gadamer, mas um acontecimento. Talvez um dos problemas da hermenêutica resida na dificuldade de separar, clara e distintamente, o que é método e conteú-

84 "La philosophie est une possibilité finie de l'homme fini; elle est une compréhension de l'être, qu'anime un questionnement; elle est la clarté crépusculaire dans laquelle un étant, enchâssé dans sa nature, au milieu de tous les autres étants, tente de se comprendre et de se concevoir lui-même, de comprendre et de concevoir toutes les choses de l'univers, et finit par demeurer dans sa suprême sagesse" (Id., ibid., p. 12).

Stein, 1996, p. 20

Em termos poéticos vale retomar aqui, de Mário Quintana: DA ETERNA PROCuRA "Só o desejo inquieto, que não passa / Faz o encanto da coisa desejada... / E terminamos desdenhando a caça / Pela doida aventura da caçada” (In: Poesias. 9. ed. São Paulo: Globo, 1994, p. 120). 
do, sujeito e objeto, forma e matéria, experiência e abstração. Mas, isso não é um problema, é antes sua riqueza, pois sempre dará o que pensar, o que filosofar. Nessa tarefa de ver com mais clareza, de ouvir com mais acuidade, sempre estaremos às voltas com uma "perfeição relativa" do conhecimento como nos lembra Gadamer.

Se para os lógicos a circularidade hermenêutica é viciosa e deve ser eliminada, para nós ela assume uma dimensão positiva e que deve ser conservada, ampliada, retificada espiralmente. Mostramos que o pré-conceito, a pré-compreensão podem ser retificados, ratificados e/ou ampliados e o processo compreensivo comporta uma circularidade inelutável que não é viciosa porque não pretende esconder ou simplesmente confirmar os pré-juizos e pré-concepções, mas trazêlos à luz, no confronto com a tradição, corrigindo-os e/ou alargando seus horizontes. Não é vicioso porque a hermenêutica não trata de problemas estritamente lógicos, mas trata do sentido da existência e das ciências. Não é possivel romper o círculo hermenêutico, pois no conhecimento não há um grau zero, um 'paraiso perdido'. Tentamos mostrar que não se trata de rompê-lo, mas valorizá-lo como condição e pressuposto universal do saber humano mais fundamental e autêntico (consigo, com outros, com o mundo). Há sempre uma determinação de quem compreende. Uma importante contribuição da hermenêutica filosófica é que ela tenta salvar a singularidade, seja do autor, da tradição, do leitor. Não se trata de uma simples subsunção do singular no universal.

Rigorosamente, nosso trabalho constituiu-se numa circularidade entre nossas expectativas sobre o mito de Hermes, sobre o círculo hermenêutico e aquelas apresentadas pelos textos e pelo que escrevemos e refletimos. Nesse ainda não dito, no "enquanto" da hermenêutica filosófica, é que nos movemos e nos moveremos sempre. Nesse nível do não dito ainda é que podemos apresentar o que acontece. Confessamos nossa prisão e dependência mais ao dito, seja pelo mito, seja pela preocupação de validação estrutural do que ao "enquanto" da hermenêutica. Confessamos que nossa resposta à preocupação de Apel, da filosofia analítica, pela validade, pela fundamentação da hermenêutica, como mais 'científica' que hermenêutica propriamente. Em todo o caso, não é por isso que nosso trabalho pode ser considerado em vão, pois a hermenêutica não exclui do șeu campo de visão e de audição as ciências. Antes, reconhece-as em sua validade, mostrando também seus limites, seu estreitamento. Assim, confessando nossa estreiteza e contradição pelo escrito ou pretendido escrever sobre a possibilidade criativa e criadora do mito, sobre o "enquanto" não conceitual da hermenêutica assumimos nossa postura limitada que, pelo menos, servirá para apontar as possibilidades mais originárias e inesgotáveis da hermenêutica filosófica. Feliz e infelizmente movemo-nos no terreno do tematizado e isso significa assumir nossa realidade finita, mas aberta à multiplicidade de sentidos que nos possibilita. Talvez pudéssemos ainda trabalhar esse "enquanto" (do deus Hermes que vai e vem, sobe e desce) como representaçã̃o do que a hermenêutica chamou de sentido. Isso permanece como problema a ser trabalhado. Poderíamos, talvez, desenvolver ainda o "enquantọ" como 'objețo/conteúdo' da hermenêutica, como o discurso, a 
linguagem auto-referencial que trabalha sempre com objetos já diluídos como objetos. Se tentamos mostrar a validade da hermenêutica filosófica, resta-nos mostrar a validade do círculo hermenêutico.

Não desenvolvemos a relação possível entre essa concepção de hermenêutica com o aspecto metodológico, mas podemos apontar alguns elementos para uma ulterior reflexão. O método hermenêutico é a sua própria estrutura e vice-versa; ele não está posto antes da compreensão nem ao lado desta. A escada com que se sobe é a mesma com a qual se desce à compreensão. Da totalidade de sentido que buscamos, assumimos a dimensão finita e humana dessa busca e, nessa circularidade, como em círculos concêntricos, podemos ampliar nossa compreensão e constituição do sentido sem pretender chegar a um término, a um fundamento inconcusso como pretendeu, por exemplo, o racionalismo cartesiano.

$\mathrm{Na}$ epígrafe inicial vimos que "o diálogo que está em. curso se subtrai a qualquer fixação" e nós concluímos, parafraseando Gadamer, que "o círculo hermenêutico, que está presente e constitui todạ compreensão, se subtrai, como Hermes em etemo movimento, sem moradia fixa, a qualquer fixação, a qualquer moradia, a qualquer doutrina ou credo. Péssima a hermenêutica que pode ou pretende acabar a circularidade do saber em nome da filosofia, que "crê que pode ou deve ficar com a última palavra'.

\section{Referências bibliográficas}

ADORNO, T. Teoria estética. São Paulo: Martins Fontes, 1970.

BRANDÃO, J. de Souza. Mitologia grega. Petrópolis: Vozes, 1986. v. 2.

CALVINO, Italo. Seis propostas para o próximo milênio: liçōes americanas. São Paulo: Companhia das Letras, 1998.

CORETH, E. Questôes fundamentais de hermenêutica. São Paulo: EPU, Ed. da Universidade de São Paulo, 1973.

FINK, E. Le Jeu comme symbole de monde. Paris: Minuit, 1966.

GADAMER, H. G., Hermeneutik I. Wahrheit und Methode. GWI. - Hermeneutik II. Wahrheit und Methode. GWII.

. Hermeneutik im Rückblick. GW10.

. Verdade e método I. Petrópolis: Vozes, 1997.

. Verdad y metodo II. Salamanca: Sigueme, 1992.

HEIDEGGER, M. Ser e tempo. Parte I. Petrópolis: Vozes, 1989.

LAKOFF, George, JOHNSON, Mark. Metaphors we live by. Chicago and London: The University of

Chicago Press, 1980.

STEIN, E. Aproximaçōes sobre hermenêutica. Porto Alegre: EDIPUCRS, 1996.

- Seis estudos sobre 'Ser e tempo'. Petrópolis: Vozes, 1990.

WEINSHEIMER, J. C. Gadamer's hermeneutics: a reading of 'Truth and method'. New Haven and London: Yale University Press, 1985. 